\title{
ÇALIŞANLARIN ADALET ALGILARI AÇISINDAN ÖRGÜTSEL GÜVEN İLE ÖRGÜTSEL BAĞLILIĞIN KARȘILAȘTIRILMASI: BANKACILIK SEKTÖRÜNDE BİR UYGULAMA
}

\author{
COMPARISON OF ORGANIZATIONAL COMMITMENT AND ORGANIZATIONAL \\ TRUST, IN TERMS OF JUSTICE PERCEPTIONS OF EMPLOYEES: AN APPLICATION \\ ON BANKING SECTOR
}

\begin{abstract}
Mehmet METE ${ }^{1}$
Cenk AKSOY ${ }^{2}$

\section{$\ddot{O} \mathbf{z}$}

$\mathrm{Bu}$ çalışmada örgütlerde adaletli davranışlar sonucu ortaya çıkan güven faktörünün, örgütsel bağlllık üzerinde bir etkisi olup olmadığının ortaya konulması amaçlanmıştır. Ayrıca işgörenlerin adalet, güven ve bağl1lık algılamalarının; yaş, cinsiyet, medeni durum, eğitim durumu ve iş tecrübesi değişkenlerine göre farklılaşıp farklılaşmadığı tespit edilmeye çalışılmıştır. Araştırma kapsamında, kamu ve özel sektör banka şubelerinde çalışan personele adalet algısı, örgütsel güven, örgütsel bağl1lık ölçekleri ile demografik değişkenler ile alakalı soruları içeren anketten 160 tane dağıtılmış, ancak bunlardan 120'si değerlendirmeye tabi tutulmuştur. Verilerin analizinde SPSS 18.0 istatistik programı kullanılmıştır. Araştırmada elde edilen veriler, araştırmanın amacı doğrultusunda çeşitli istatistik metod ve test teknikleri (frekans dağılımı, ortalama, t-testi, ANOVA, regresyon, korelasyon) kullanılarak yorumlanmıştır. İstatistikî anlamlılık düzeyi $\mathrm{p}<0.05$ olarak kabul edilmiştir. Araştırmaya katılan işgörenlerin adalet algısı açısından örgütsel güven ile örgütsel bağlılık arasında istatistiksel bir ilişki olup olmadığı araştırılmış, korelasyon katsayısı 0,634 olarak hesaplanmıştır. Yapılan analizde korelasyon katsayısının anlamlılı̆ğın yüksek olduğu tespit edilmiştir. Buna göre işgörenlerin adalet algısı açısından örgütsel güven ile örgütsel bağlllık arasında pozitif doğrusal bir ilişki olduğu tespit edilmiştir.
\end{abstract}

Anahtar Kelimeler:Örgütsel Bağlılık, Örgütsel Güven ve Adalet Algısı.

\begin{abstract}
In this study, organizational commitment factor and trust factor in terms of justice perceptions of employees in the banking sector was questioned. In addition, it is aimed to determine employees perceptions of justice, trust and commitment whether differed according to variables of age, sex, marital status, educational status and work experience. The survey of public and private sector personnel working in bank branches and organizational commitment, organizational trust and organizational justice scale and demographic variables, including questions related to the questionnaire distributed at 160, but 120 of them was evaluated. The findings of the study were evaluated analyzed through SPSS 18.0 statistical package program, using frequency, mean, t-test, one-way anova, regression and correlation analysis. The level of significance was taken as 0,05 . A liner relationship was found among organizational commitment, organizational trust and organizational justice. In the analysis the correlation coefficient was calculated to be 0.634. It was found that the significance of the correlation coefficient is high. The result of the study reveals that there is a positive linear relation between organizational trust, measured through the scales of justice and organizational commitment.
\end{abstract}

Key Words: Organizational Commitment, Organizational Trust and Perception of Justice.

\footnotetext{
${ }^{1}$ Yd.Doç.Dr., Dicle Üniversitesi, iïBF, İşletme Bölümü, mmete@yahoo.com

${ }^{2}$ Arş.Gör., Dicle Üniversitesi, Sivil Havacılık Yüksekokulu, cenk.aksoy@dicle.edu.tr
} 


\section{GíRíș}

Örgütler, hedeflerine ulaşabilmek için insan kaynağına büyük önem vermek durumundadır. Bir değer olarak gördüğü işgörenlerine sürekli yatırım yapmak ve yatırım yaptığ 1 bu işgörenlerin örgütte kalmalarını sağlayarak etkinliklerini arttırmak için örgüte olan bağlılıklarını arttırmak zorundadır. İşgörenlerin, örgütlerine bağlanabilmeleri adına örgütlerine güven duymaları çok önemlidir. Oluşturulacak olan güven ortamında işgörenler daha verimli ve performanslı olarak çalışabilecek bu da örgütün karlılığını arttırmasına sebep olacaktır. Güven ortamının oluşumunda ise belki de en temel yapıtaşı olabilecek kavram adalet algısı olarak karşımıza çıkmaktadır. Adil uygulamalarının olduğu bir örgütte işgörenlerin motivasyonları artmakta, haksız uygulamalarla karşılaşan işgörenlerin ise örgütlerine duydukları güven azaltmaktadır. Güven duygusu zedelenen işgörenlerin örgüte olan bağl1lıkları zayıflamakta, bu durum da işgörenlerin örgütlerinden ayrılmalarına, devamsızlığa ve performans düşüklüğüne sebep olabilmektedir.

Finans sektöründe önemli bir konuma sahip olan bankaların etkinlik ve verimliliklerini arttırabilmek için kendilerini geliştirmeleri, değişime uygun nitelikte bir insan kaynakları yapısına sahip olmaları gerekmektedir. Hizmet sektörü açısından büyük önem taşıyan bankaların insan kaynakları yapılarında, yeniden yapılanma ile birlikte yaşanan değişime bağlı olarak örgütsel bağlılık, adalet ve güven konularında da önemli çalışmalar yapılması gerektiğini vurgulayabilmek adına böyle bir çalışma gerçekleştirilmiştir.Literatürde bankacılık sektöründe çalışanların adalet algıları açısından örgütsel güven ile örgütsel bağlılık düzeylerinin araştırılması ile ilgili olarak az sayıda çalışma olduğundan, konuyla ilgili çalışmaya karar verilmiştir. Araştırma kapsamında elde edilen verilerle, banka sahiplerine, banka yöneticilerine ve konuyla ilgili akademisyenlere veri sağlayarak faydalı olunması amaçlanmıştır.

Çalışmada genel hatlarıyla örgütsel bağlılık, adalet ve güven kavramlarına yer verilmiştir. Bunun sonucunda da alan araştırması kapsamında; bu kavramlar arasındaki ilişki bankacılık sektöründe incelenerek geliştirilmesi gerekli görülen fonksiyonlara ilişkin öneriler sunulması amaçlanmıştır.

\section{LITERARATÜR TARAMASI}

\section{1. Örgütsel Bağlılık}

Örgütsel bağlılık, özellikle örgütsel davranış alanında kullanılan bir kavram olarak karşımıza çıkmakta olup, uzun yıllar akademisyenler tarafından üzerinde araştırmaların yapıldığı bir odak haline gelmiştir.Yapılan çalışmalar, örgütsel bağlılık kavramının işgörenlerin örgüt ile ilişkilerini nitelendiren psikolojik bir durumu ifade ettiği konusunda ortak bir noktada birleşmektedir.İşgörenler örgüt için faaliyet göstermekte ve zihinlerinde oluşturdukları örgütsel izlenimlere göre işgörenlerin örgütsel bağlılık düzeyleri değişmektedir (Güçlü, 2006: 8).Bu alanda yapılan çalışmalara en önemli katkıyı sağladığı düşünülen Meyer ve Allen'a göre örgütsel bağl1lık kavramı "bireyi örgüte bağlayan psikolojik bir durum" olarak tanımlanmaktadır.Ayrıca Meyer ve Allen, örgütsel bağlılığın duygusal bağlılık, devam bağlılığı ve normatif bağl1lık şeklindeki üç bileşenden meydana geldiğini belirtmektedirler.İsgörenleri örgüte bağlayan psikolojik bir durumu yansıtan örgütsel bağl1lık kavramının tanımı hakkında araştırmacılar açısından farklı bakış açıları bulunmaktadır. Söz konusu bu araştırmacılar açısından yapılan tanımlar şu şekildedir (akt. Bakan, 2011: 8-10):

- Örgütün amaç ve değerleri ile bireyin amaç ve değerlerinin bütünleşmesi ve uyumlaşması sürecidir (Hall ve ark., 1970: 176).

- Kişinin belirli bir örgüte karşı ilgisi ve örgütle kendini tanımlamasının göreceli olarak derecesidir (Mowday ve ark., 1979: 224). 
- Kişinin örgütsel amaçlar ve özellikleri içselleştirmesi ve örgüte adapte olmasını sağlayan örgüte yönelik hissettiği psikolojik ilgi ve bağlanmasıdır (O'Reilly ve Chatman, 1986: 492).

- İşgörenin çalıştı̆ğ işletmede işine devam etme isteğinde olması, işyerine düzenli olarak gelmesi, işletmenin varlıklarını koruması ve işletmenin amaçları ile bütünleşmesidir (Meyer ve Allen, 1997).

\section{2. Örgütsel Güven}

Örgütsel güven, otuz y1lı aşkın bir süredir yönetim biliminde araştırma konusudur (Wahlstrom ve Louis, 2008: 458). Örgüt içinde güven temeline dayanan ilişkilerin kurulabilmesi, amaçlara ulaşmada ve etkili bir ekip kurmada oldukça önemli bir unsurdur. Güvenin tam olarak yerleşmediği örgüt ortamlarında ise etkili ekiplerin kurulabilmesi, takım çalışmalarının gerçekleştirilebilmesi ve belirlenen hedeflere ulaşılabilmesi oldukça güçtür (Asunakutlu, 2001: 5).

Örgütsel güven, örgüt çalışanlarının örgütün eylemlerine karşı savunmasız kalmaya istekli olmaları olarak tanımlanmaktadır (Tan ve Lim, 2009: 45). Örgütsel güven, örgütte çalışan herkesin hissettiği güven ve destektir (Y1lmaz ve Atalay, 2009: 341). Örgütsel güven kavramı ile ilgili literatürde birçok tanım bulunmaktadır (Polat, 2007: 46):

- Örgütsel güven, yöneticilerin verdikleri sözün arkasında duracaklarına dair çalışanların besledikleri inançtır (Mishra ve Morrissey, 1990).

- Örgütsel güven, örgütteki kişiler arası güvenin örgüte genelleştirilmesi ve başka bir deyişle, örgüte olan toplu yönelimi ifade eder (Zaheer ve ark., 1998).

- Örgütsel güven, örgüt üyelerinin iyiliği için karşılıklı saygıya ve nezakete dayalı uyumlu davranışların bir sonucu olarak kazanılan bir olgudur (Taylor, 1989).

Son yıllarda güven kavramı yönetim araştırmalarında sıkça yer almaktadır (Becerra ve Gupta, 2003: 32). Örgüt içinde güven ortamının oluşması, astlar ve üstler arasında güvene dayalı ilişkilerin kurulması örgütsel performansı, üretkenliği ve örgütsel bağl1lığ etkilemektedir (Straiter, 2005: 86). Örgütlerde güvene dayalı ilişkilerin kurulması ve çalışanların liderlerine ve bir bütün olarak örgütlerine güven duymaları, örgütlerine duygusal açıdan bağlı, kendilerini örgütleri içinde tanımlayabilen, işlerinden tatmin olan ve örgütlerinden ayrılmak istemeyen çalışanlar oluşturabilir. Bu olumlu sonuçların ortaya çıkabilmesi için çalışanların liderlerine ve örgütlerine güven duymalarında etkili olan faktörlerin ve güveni ortaya çıkaran etmenlerin anlaşılması gerekmektedir (Demircan ve Ceylan, 2003:139).

Örgütsel güven, riskli durumlarda bile çalışanın, örgütün uygulamalarından ve politikalarından emin olması ile bu uygulamalara ve politikalara karşı olumlu beklentilere sahip olmasıdır. Bu bakımdan, örgütsel güven çalışanın örgütsel destek anlayıșını ve yöneticilerin güvenilir olduğuna dair inancını yansıtan ve örgütün insan ilişkilerinde açık, duyarlı ve güvenilir olması ile ilgili bir kavram olarak değerlendirilebilir. Örgüt içinde güvenilir bir atmosferin oluşturulması örgütsel gelişimin temellerini atacaktır. Güven ortamının sağlandığı örgütlerde, açık ve paylaşımcı bir örgüt iklimine, sorumluluk duygusu taşıyan çalışanlara, etkili üretime ve örgütsel bağlılığa, takım çalışmasına, iş doyumuna ve karara katılım süreçlerine tanık olmak mümkündür (Yılmaz, 2008: 2293-2299).Örgütsel güvenin yüksek olduğu örgütlerde örgüt üyeleri arasında bir uyumdan ve bütünlükten bahsetmek mümkündür. Örgütsel güvenin sağlandığı ortamlarda örgüt üyeleri birbirlerine güvenir ve dürüst davranırlar. Örgütle ve örgütsel amaçlarla daha iyi özdeşleşirler. Bu tür örgütlerde çalışanlar daha yapıcı olurlar ve daha yenilikçi fikirler üretebilirler (Aktuna, 2007). 


\section{3. Örgütsel Adalet}

Bütün sosyal ortamlarda var olması bu kadar önemli olan adalet kavramının örgütlerde ihmal edilmesi ise imkânsızdır. Ancak adaletin örgütlerde dikkat edilen bir kavram olarak araştırılması hukuk ve sosyal bilimler alanlarında araştırılmasına göre nispeten daha yeni bir konudur (Çakmak, 2005: 19).

Örgütlerde adalet konusunun araştırılmasının son otuz yıldan uzun bir zamandır önem kazandığı görülmektedir. İşte 1960-1970'lerden beri iş ortamında dikkat edilen, önem verilen bir konu olarak adaleti açıklama ve tanımlama çabaları örgütsel adalet adı verilen yeni bir literatürün gelişmesine yol açmıştır (Greenberg, 1990: 400).

Örgütsel adalet, örgütsel kaynakların (ödül ve cezalar) dağıtımının, bu dağıtım kararlarını belirlemede kullanılan prosedürlerin ve bu prosedürlerin yürütülmesi sırasında gerçekleşen kişiler arası davranışların nasıl olması gerektiği ile ilgili kurallar ve sosyal normlar bütünü olarak izah edilmektedir (Folger ve Cropanzono, 1998: 110-111).

Günümüzde yoğunlaşan rekabet nedeniyle örgütlerin ayakta kalabilmeleri çalışanlarından istedikleri verimliliği elde etmelerine bağlıdır. Örgütlerin çalışanlarından istedikleri verimliliği elde etmeleri ise çalışanlarının iş tatmin, motivasyon, performans düzeylerine bağlıdır. Örgütsel adalet kavramı, çalışanların örgütleri hakkındaki düşüncelerini ve bu düşünceleri doğrultusunda örgütlerine karşı nasıl bir tutum ve davranış içine gireceklerini belirlemede çok önemli bir konudur (Cohen-Charash ve Spector, 2001: 278279).

Buna göre çalışanların örgütlerini adil algılamamaları durumunda, verimliliklerini etkileyen önemli birer unsur olan iş tatmini, motivasyon ve performans düzeylerinde de bir düşüş yaşadıkları gözlenmiştir. Ayrıca çalışanların devamsızlıklarının, işten ayrılma niyetlerinin arttığ1 görülmüş ve örgütlerde yaşanan stres ve gerginliğin en üst seviyeye ulaştığ belirlenmiştir (Schminke ve ark., 2000: 294). Çalışanların örgütlerine karşı tutum ve davranışlarını ve örgütün verimliliğini belirlemede önemli bir yeri bulunan örgütsel adalet kavramı örgütlerin üzerinde dikkatle durmaları gereken bir konu olarak karşımıza çıkmaktadır (Çakmak, 2005: 21).

\section{4. Örgütsel Bağlılık ve Örgütsel Güven İlişkisi}

Birey bir örgütün üyesi olduğu ilk günden itibaren gerek örgüt gerekse yöneticileri hakkında bilgiler edinerek, örgüte ve yöneticilerine ne oranda güvenebileceğini belirlemeye çalışır. Şayet edindiği deneyimler hem örgütü hem de yöneticilerini güvenilir kılmaya yönelik ise, bireyin örgüte olan bağlılığ 1 da artmış olur. Hiçbir insan güven ortamının olmadığ bir yerde veya grupta bulunmayı arzulamaz. İnsanların en mutlu oldukları yer ve zamanlar, kendilerini güvende hissettikleri zamanlardır. Bu nedenle örgütsel güven ile örgütsel bağl1lık arasında anlamlı bir ilişki bulunmaktadır (Bakan, 2011: 168-169).

Yeni nesil örgütlerin temel sorunlarından birisi olan örgütsel bağlılık oluşturma, güven temelli bir örgütsel yapılanmayı zorunlu kılmaktadır. Örgütsel bağlılık oluşturma, örgütte etkili bir güven ortamının varlığı ve sürekliliğine bağlı olarak sonuç doğuracaktır. Örgütsel güven oluşturma ve geliştirme yeteneklerini iyi organize edebilen örgütler, çalışanların bilgi, yetenek ve tecrübelerinden en yüksek getiriyi elde etmekle yetinmeyecek, örgütsel bağlılık oluşturma konusunda da daha avantajlı olacaklardır (İnce ve Gül, 2005; Demirel, 2008).

Örgütün kendilerine adil ve eşit bir şekilde davrandığına güvenen bireyler örgütlerinden ayrılmayı düşünmezler. Bu bireyler gösterdikleri en küçük çabanın örgüt tarafından bilindiğine ve karşılığının kendilerini mutlu edecek şekilde verildiğine inanırlar. $\mathrm{Bu}$ durumun aksine, aşırı iş yükü karşılığında üyelerinin beklentilerini karşılayamayan bir 
örgüte duyulan güven zayıflayacak ve örgüt üyeleri ilk firsatta örgütü terk etme eğilimi göstereceklerdir (Benkhoff, 1997: 114). Ancak unutulmamalıdır ki, örgütsel bağlılığın temelinde gönüllülük ve içtenlik yatmaktadır. Dolayısıyla örgüte bağlılık duyan bir birey mutlaka gösterdiği çaba ile aldığı ödülün eşit olmasını bağlllık için ön koşul olarak ileri sürmez. Birey bağlılık duyduğu örgütün amaçlarına ulaşabilmesi için özveri ile en yüksek düzeyde çaba sarf eder, bunun sonucunun mutlaka bir ödüllendirme olmasını her zaman düşünmez. Ancak, örgüte çalışmak için üye olan bireylerin kendi bireysel beklentileri (gelir elde etmek gibi) de bulunduğundan, örgütün kendisine bağlılık duyan ve özveriyle görevlerini yerine getiren üyelerini ödüllendirmesi bir gerekliliktir (Bakan, 2011: 169).

Güvenin örgütsel bağlılık üzerinde etkisi olduğu yönünde literatürde çok sayıda araştırma yapılmış ve araştırmaların hemen hepsinde güven ile örgütsel bağlılık arasında pozitif ilişki bulunmuştur (Bansal ve ark., 2004: 234; Ruyter ve Wetzels, 1999: 57).

\section{5. Örgütsel Adalet ve Örgütsel Güven İlişkisi}

Örgütsel güven, prosedürel adalete bağlı olarak gelişmekte ve dağıtımsal adalet ile etkileşimi yoluyla kaynakların dağıtımına ilişkin kararlara gösterilen tepkileri belirlemektedir. Prosedürel adalet alınan kararların yapısına ve kararları alan kişilerin kişilerarası davranışlarına (etkileşimsel adalet) dayanmaktadır. Bu tür adaletin yapısal ve kişilerarası unsurlarının her ikisi de algılanan güveni etkilemektedir ancak etkileşim süreci farklılık göstermektedir. Prosedürel adaletin yapısal yönünün (karar veya süreç kontrolu) kalıcı olma özelliği belirsizliği azaltmakta ve kararların yapısına bağlı olarak gelişen geleceğe yönelik tahminlerin yapılmasını kolaylaştırmaktadır. Karar veren kişilerin geliştirdikleri kişilerarası ilişkiler, etkileşimsel adalete ilişkin algılamaları belirlemektedir. Yapısal ve etkileşimsel açıdan adil olan prosedürler sisteme ve karar alan kişilere güven duyulmaasını sağlamaktadır. Bunun tersine adil olmayan prosedürler de düşük düzeyde güven oluşumuna neden olmaktadır. Alexander ve Ruderman (1987), prosedürel ve dağıtımsal adalete ilişkin algılamaların, üst düzey yöneticilere duyulan güveni belirlediğini ifade etmişlerdir. Folger ve Konovsky (1989), yöneticilerin adil prosedürlere dayanan uygulamalarının, insan kaynaklarının sisteme bağlılık duymaları ve yöneticilerine güvenmeleri sonucunu doğuracağı, Pillai ve arkadaşları da (1999), insan kaynaklarına yönelik adil davranışların, onların güvenini, hedeflere bağl1lıklarını arttıracağı ve sıra dışı bir performans düzeyi oluşturacağ1 şeklindeki ifadeleri de bu görüşü desteklemektedir. Onlara göre adil prosedürler, yöneticinin insan kaynaklarının haklarına saygı duyduğunun ve onlara değer verdiğinin göstergesidir (İşbaş1, 2000: 82-83).

\section{6. Örgütsel Adalet ve Örgütsel Bağlılık İlişkisi}

Yapılan bazı araştırmalarda örgütsel adalet ile örgütsel bağlılık arasında pozitif bir ilişki olduğu ortaya konulmuştur (Dailey ve Kirk, 1992: 305; Sweeney ve Mcfarlin, 1993: 23). Dolayısıyla kaynakların adil dağılımı ile örgütsel bağlılık arasında bir ilişki bulunmaktadır (Brewer, 1996: 24). Örgütsel faydanın, insan kaynaklarına adaletli bir şekilde dağıtılmasını kapsayan dağıtımsal adalet, insan kaynaklarının örgüte olan bağlılıklarını arttırıcı yönde etkiye sahiptir (Özler, 2010: 52). Örgütsel ödül ve kaynakların adil şekilde dağıtılmadığı yönünde bir algıya sahip olan bireylerin ise örgütsel bağlılıkları olumsuz yönde etkilenecektir (Organ, 1988: 547). Çalışanlar örgüt kaynaklarından eşit düzeyde yararlanarak hem görevlerini daha başarıyla tamamlamak hem de ortaya çıkan sonuçlardan performansları ölçüsünde faydalanmak isterler (Bakan, 2011: 194).

Çalışanlar, performansları karşılığında örgütlerin adil ve yansız çıktılar sağladığını algıladıklarında örgüte daha fazla bağlanma eğiliminde olmaktadırlar. Cropanzano ve Folger (1991), prosedürel davranışların açık ve net olmasının örgütsel bağlılık üzerinde etkiye sahip olduklarını belirtmektedirler. Orpen (1994), örgüt içinde dağıtımsal adalet sağlandığı zaman 
insan kaynaklarının yüksek düzeyde örgütsel bağlılık göstereceklerini belirtmektedir. Dağıtımsal adaletin etkin bir biçimde uygulanmaması, insan kaynaklarında emeklerinin karşılığını alamadıkları düşüncesine neden olmakta ve örgüte olan bağlılıklarını da olumsuz yönde etkilemektedir (Özler, 2010: 52).

\section{Araştırmanın Hipotezleri}

Araştırmanın amacı, örgütlerde adaletli davranışlar sonucu ortaya çıkan güven faktörünün, örgütsel bağlılık üzerinde bir etkisi olup olmadığının ortaya konulması, eğer etkisi varsa da bunun derecesini ortaya çıkarmak ve işgörenlerin adalet, güven ve bağlılık algılamaları; yaş, cinsiyet, medeni durum, eğitim durumu ve iş tecrübesi değişkenlerine göre farklılaşıp farklılaşmadığını tespit etmektir. Araştırmanın hipotezleri şu şekilde belirlenmiştir:

$\mathrm{H}_{1}$ : İşgörenlerin adalet algıları açısından örgütsel güven ile örgütsel bağlılık arasında pozitif doğrusal bir ilişki vardır. vardir.

$\mathrm{H}_{2}$ : İşgörenlerin adalet algılarının, örgütsel bağl1lık ve örgütsel güven üzerinde etkisi

\section{ARAŞTIRMA}

Araştırmanın Yöntemi:Bu çalışmada, Diyarbakır ilinde faaliyet gösteren özel ve kamu sektörü banka çalışanlarına yönelik bağlılık, adalet ve güven ölçeği uygulanmıştır. Dağıtılan 160 anketten, 128'i geri dönmüş ancak 8'i değerlendirme dışında tutulmuştur.Geriye dönüş oran $1 \% 75$ olmuştur.

Araştırmanın Modeli: Literatürden yararlanarak elde edilen hipotezlerden örgütsel bağlılık, örgütsel güven ve örgüt adalet arasında doğrusal bir ilişkiyi gösteren aşağıdaki kavramsal model geliştirilebilir (Şekil 1).

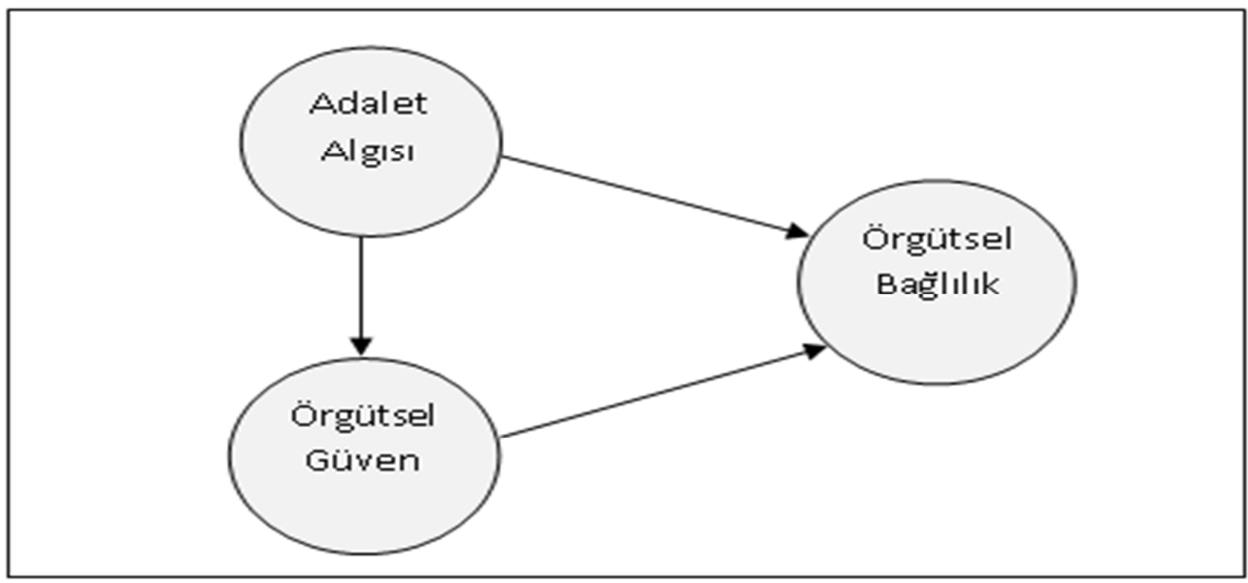

\section{Şekil 1.Araştırmanın Modeli}

Araştırmanın Evreni ve Örneklemi: Türkiye Bankalar Birliği verilerine göre Türkiye'de bankacılık sektöründe bankaların şube sayısı 9465'dir. Araştırma evrenini, Diyarbakır ilinde faaliyet gösteren 78 banka şubesinin 1207 çalışanı oluşturmaktadır (www.tbb.org.tr).

Veri Toplama Araçları: Verilerin toplanmasında; yaş, cinsiyet, öğrenim durumu, medeni durum ve iş tecrübesi gibi özellikler yer alan demografik bilgiler formu ile literatürden yaralanılarak elde edilen toplam 13 maddeden oluşan bir ölçek kullanılmıştır. Örgütsel bağl1lığın ölçülmesinde 1-5 arasındaki sorular Mowday, Steers ve Porter (1979: 228, akt. Fields, 2002: 47) tarafindan hazırlanan ölçek, örgütsel adaletin ölçülmesinde 6-9 arasındaki sorular Sweeney ve McFarlin (1993: 27, akt. Fields, 2002: 174) tarafindan 
hazırlanan ölçek, örgütsel güvenin ölçülmesinde ise 10-13 arasındaki sorular Nyhan ve Marlowe (1997, akt. Ertürk, 2008: 462) tarafından hazırlanan ölçek kullanılmıştır.Her üç ölçeğinde ifadelerinde düzeltmelere gidilmiştir.Anket formunda yer alan ifadelere katılımcıların ne derecede katıldığını belirlemek için 5'li Likert ölçeği kullanılmıştır. Buna göre ifadeler, "Kesinlikle Katılmıyorum (1)", "Katılmıyorum (2)", "Kismen Kat1liyorum (3)", "Katılıyorum (4)", "Tamamen Katılıyorum (5)" olarak sıralandırılmıştır.

Verilerin Analizi:Verilerin değerlendirilmesinde SPSS 18.0 istatistik programı kullanılmıştır. Araştırmada elde edilen veriler, araştırmanın amacı doğrultusunda çeşitli istatistik metod ve test teknikleri (frekans dağılımı, ortalama, t-testi, ANOVA, regresyon, korelasyon) kullanılarak yorumlanmıştır. Verilerin değerlendirilmesi, katılımcıların her bir soruya verdikleri cevapların toplam puanları üzerinden yapılmıştır. İstatistikî anlamlılık düzeyi $\mathrm{p}<0.05$ olarak kabul edilmiştir.

\section{BULGULAR}

Araştırmaya katılanlarla ilgili bazı demografik bilgiler Tablo 1.'de gösterilmiştir. $\mathrm{Bu}$ tabloda görüldügü gibi araştırmaya 120 kişi katılmış olup, bayanların oranı \%27,5 ve erkeklerin oran 1 ise $\% 72,5$ 'dir. Medeni durum açısından değerlendirildiğinde evlilerin oranı \%69,2 ve bekârların oranı \%30,8'dir. Katılımcıların \%33,3'ü lise, \%57,5'i ise üniversite mezunudur. Yaş durumuna bakıldığında 20-30 yaş aralığındaki personel sayısı \%20 iken, 3140 yaş aralığı $\% 32,5,41-50$ yaş arası $\% 29,2$ ve 50 yaş üstü personel sayısı ise $\% 18,3$ 'lük paya sahiptir. İş tecrübelerine bakıldığında 1-5 y1l arası tecrübelilerin \%15 olduğu görülürken, 6-10 y1l arası $\% 14,2,11-15$ yıl arası $\% 23,3,16-20$ yıl arası 13,3, 20 ve üzeri yıl iş tecrübesine sahip olanlar ise \%34,2 olarak ortaya çıkmıştır.

Tablo 1. Demografik Değişkenler

\begin{tabular}{|l|c|c|l|c|c|}
\hline \multicolumn{1}{|c|}{ Değişkenler } & Frekans & $\mathbf{( \% )}$ & Değişkenler & Frekans & (\%) \\
\hline Cinsiyet & & & & & \\
\hline Erkek & 33 & 27,5 & İlköğgretim & 3 & 2,5 \\
\hline Kadın & 87 & 72,5 & Lise & 40 & 33,3 \\
\hline Toplam & 120 & 100 & Üniversite & 69 & 57,5 \\
\hline Yaş & & & Lisansüstü & 8 & 6,7 \\
\hline $20-30$ & 24 & 20.0 & Toplam & 120 & 100 \\
\hline $31-40$ & 39 & 32,5 & İş Tecrübesi & & \\
\hline $41-50$ & 35 & 29,2 & $1-5$ y1l & 18 & 15,0 \\
\hline 50 ve üzeri & 22 & 18,3 & $6-10$ yıl & 17 & 14,2 \\
\hline Toplam & 120 & 100 & $11-15$ yıl & 28 & 23,3 \\
\hline Medeni Durumu & & & $16-20$ y1l & 16 & 13,3 \\
\hline Evli & 83 & 69,2 & 20 ve üzeri y1l & 41 & 34,2 \\
\hline Bekâr & 37 & 30,8 & Toplam & 120 & 100 \\
\hline Toplam & 120 & 100 & & & \\
\hline
\end{tabular}




\section{Analizi}

\section{Örgütsel Adalet, Örgütsel Güven ve Örgütsel Bağlılık Arasındaki Korelasyon}

Tablo 2.Örgütsel Adalet, Güven ve Bağlılık Arasındaki İlişki

\begin{tabular}{|c|c|c|c|}
\hline & $\begin{array}{c}\text { Örgütsel } \\
\text { Bağlılık }\end{array}$ & $\begin{array}{c}\text { Örgütsel } \\
\text { Adalet }\end{array}$ & $\begin{array}{c}\text { Örgütsel } \\
\text { Güven }\end{array}$ \\
\hline $\begin{array}{c}\text { Örgütsel } \\
\text { Bağlılık }\end{array}$ & 1 & 1 & \\
\hline $\begin{array}{c}\text { Örgütsel } \\
\text { Adalet }\end{array}$ & $0,651^{* *}$ & $0,665^{* *}$ & 1 \\
\hline $\begin{array}{c}\text { Örgütsel } \\
\text { Güven }\end{array}$ & $0,634^{* *}$ & & \\
\hline
\end{tabular}

**. Korelasyon 0,01 seviyesinde anlamlı (çift yönlü). ilişki vardır.

$\mathrm{H}_{1}$ : İşgörenlerin adalet algısı açısından örgütsel güven ile örgütsel bağlılık arasında

Tablo 2.'dearaştırmaya katılan işgörenlerin adalet algısı açısından örgütsel güven ile örgütsel bağlılık arasında istatistiksel bir ilişki olup olmadığı araştırılmış, korelasyon katsayısı 0,634 olarak hesaplanmıştır. Yapılan analizde bulunan korelasyon katsayısının anlamlılığının yüksek olduğu tespit edilmiştir.Buna göre işgörenlerin adalet algısı açısından örgütsel güven ile örgütsel bağlılık arasında anlamlı bir ilişki vardır.Başka bir deyişle $\mathrm{H}_{1}$ hipotezi desteklenmiştir.

Tablo 2.adalet algısının oluşturduğu güvenin örgütsel bağlılık üzerinde güçlü bir etkisi olduğunu göstermiştir. İşgörenlere karşı adaletli olan davranışlar, işgörenlerin örgüte güven duymasını sağlamakta bu da sonuç olarak örgütsel bağlılığı doğurmaktadır.

\section{Analizi}

Örgütsel Bağlılık ile Örgütsel Güven Arasındaki Determinasyon Katsayısı

Tablo 3.Örgütsel Bağl1lık ile Örgütsel Güven Arasındaki Determinasyon Katsayısı Hesab1

\begin{tabular}{|c|c|c|}
\hline Belirleme Katsayısı & $\begin{array}{c}\text { Düzeltilmiş } \\
\text { BelirlemeKatsayısı }\end{array}$ & Standart Sapma \\
\hline 0,404 & 0,399 & 3,97941 \\
\hline
\end{tabular}

Bağımlı değişkenin, bağımsız değişkene hangi oranda bağlı olduğunu göstermeye yarayan katsayı olan determinasyon katsayısı, bu çalışmada yer alan "örgütsel bağlılık" bağımlı değişkeninin "örgütsel güven” bağımsız değişkenine hangi oranda bağlı olduğunu belirlemek için hesaplanmış ve örgütsel bağlılık değişkeninde örgütsel güven değişkeninin ne kadar etkili olduğu saptanmıştır. Örgütsel güvenin, örgütsel bağl1lı̆̆ı açıklama düzeyi (R Kare $=0,404$ ) olarak tespit edilmiştir. vardir.

$\mathrm{H}_{2}$ : İşgörenlerin adalet algılarının, örgütsel bağlılık ve örgütsel güven üzerinde etkisi

$\mathrm{H}_{2 \mathrm{a}}$ : İşgörenlerin adalet algılarının, örgütsel bağlılık üzerinde etkisi vardır.

Tablo 2.'de araştırmaya katılan işgörenlerin adalet algısı ile örgütsel bağlılık arasında istatistiksel bir ilişki olup olmadığı araştırılmış, korelasyon katsayısı 0,651 olarak hesaplanmıştır. Yapılan analizde bulunan korelasyon katsayısının anlamlılığının yüksek 
olduğu tespit edilmiştir.Buna göre işgörenlerin adalet algısı ile örgütsel bağlılık arasında anlamlı bir ilişki vardır.Başka bir deyişle $\mathrm{H}_{2 \mathrm{a}}$ hipotezi desteklenmiştir.

$\mathrm{H}_{2 \mathrm{~b}}$ : İşgörenlerin adalet algılarının, örgütsel güven üzerinde etkisi vardır.

Tablo 2.'de araştırmaya katılan işgörenlerin adalet algısı ile örgütsel güven arasında istatistiksel bir ilişki olup olmadığı araştırılmış, korelasyon katsayısı 0,665 olarak hesaplanmıştır. Yapılan analizde bulunan korelasyon katsayısının anlamlılığının diğer ilişkilerle kıyasla en yüksek olduğu tespit edilmiştir.Buna göre işgörenlerin adalet algısı ile örgütsel güven arasında anlamlı bir ilişki vardır.Başka bir deyişle $\mathrm{H}_{2 b}$ hipotezi desteklenmiştir.

\section{TARTIŞMA ve SONUÇ}

Araştırmada, güven faktörü, adalet algısı ölçütüyle ele alınmış ve örgütsel bağlılıkla olan ilişkisi araştırılmıştır.Araştırma sonucunda araştırma problemini destekleyen sonuçlar elde edilmiştir. Araştırmada yapılan testler ve analizler kapsamında elde edilen sonuçlar aşağıdaki gibidir:

1. Araştırmada işgörenlerin adalet algıları açısından örgütsel güven ile örgütsel bağlılık arasında ilişki olup olmadığına bakılmış olup, böyle bir ilişkinin olduğu tespit edilmiştir. Dolayısıyla $\mathrm{H}_{1}$ hipotezi desteklenmiştir.Araştırmaya katılan işgörenlerin adalet algısı açısından örgütsel güven ile örgütsel bağlılık arasında istatistiksel bir ilişki olup olmadığı araştırılmış, korelasyon katsayısı 0,634 olarak hesaplanmıştır.Yapılan analizde bulunan korelasyon katsayısının anlamlılığının yüksek olduğu tespit edilmiştir.Buna göre işgörenlerin adalet algısı açısından örgütsel güven ile örgütsel bağlılık arasında anlamlı bir ilişki vardır.

Adalet davranışının oluşturduğu güvenin örgütsel bağlılık üzerinde güçlü bir etkisi olduğunu göstermiştir.İ̧sörenlere karşı adaletli olan davranışlar, işgörenlerin örgüte güven duymasını sağlamakta bu da sonuç olarak örgütsel bağlılığı doğurmaktadır.

2. Araştırmada işgörenlerin adalet, güven ve bağlılık algılamalarının yaş, cinsiyet, medeni durum, eğitim durumu ve iş tecrübesi değişkenlerine göre farklılaşıp farklılaşmadığına bakılmış olup, yaş, cinsiyet, eğitim durumu ve iş tecrübesine göre farklılaşmanın olmadığı tespit edilmiştir.

Medeni duruma göre böyle bir farklılaşmanın örgütsel bağlılık faktöründe olduğu tespit edilmiştir.Bu çalışmada bekârların bağlılık düzeylerinin evlilerin bağlılıkdüzeylerinden daha yüksek düzeyde olduğu görülmüştür. İncelenen bazı literatürde araştırma sonucu desteklerken bazı literature gore ise farklılaşmaktadır.Desteklenen yönüyle; işgörenlerin aile ve akrabalık sorumluluğu ya da bireyin aile ve yakınlarına olan yükümlülükleri bağlılıkta önemli bir faktördür. Aile ve akraba sorumluluğu olan işgörenlerin iş ve aile yükümlülüklerine ilişkin istemleri çatıştığında, örgüte ve uygulamalarına daha az bağlılık duydukları ileri sürülmektedir (Balay, 2000: 59).Medeni halin zorunlu bağl1lıkla ilişkili olabileceğini belirtmektedir.Bunun nedenini ise, evli bireylerin bekârlara göre genelde daha fazla finansal yük üstlenmeleri olarak açıklamaktadır.Bakmakla yükümlü olduğu kişiler daha fazla olabileceğinden bu kişilerin sorumluluk hissi yüksek olacaktır.Örgütten elde ettiği kazançlarla ailesinin geleceğini teminat altına almak isteyecektir.Bu nedenle medeni durumun devamlılık bağlılığı ile ilişkili olduğunu söylemek mümkündür (Şimşek, 2002: 21).

3. İşgörenlere yapılan bağlılık, adalet ve güven ölçeklerinin frekans dağılımı sonuçlarına göre aşağıdaki sonuçlara ulaşılmıştır;

3.1. İşgörenlere yapılan bağlılık ölçeğinin frekans dağılımı sonuçlarına göre aşağıdaki sonuçlara ulaşılmıştır; 
Birinci bağlılık ölçeği " $\mathrm{Bu}$ Kurumun başarısı için benden beklenen çabanın çok ötesinde çaba göstermeye hazırım" ifadesine katılımcıların \%86's1 "kısmen kat1liyorum, katılıyorum ya da tamamen katılıyorum" seçeneklerini işaretlemiştir. Bu durum çalışanların çoğunluk itibariyle kurumun başarısı için üst düzeyde gayret sarf edebilecek kadar kuruma bağlılık düzeylerinin yüksek olduğunu göstermektedir.

İkinci bağlılık ölçeği "Bu Kurumun bir parçası olduğumu söylemekten gurur duyuyorum." ifadesine katılımcıların $\% 75$ 'i "kısmen katılıyorum, katılıyorum ya da tamamen katılıyorum" seçeneklerini işaretlemiştir. Bu durum çalışanların çoğunluk itibariyle kurumla özdeşleştiğinin kanıtı olması açısından bağlılık düzeylerinin yüksek olduğunu göstermektedir.

Üçüncü bağlılık ölçeği "Kariyerimin geri kalanını bu kurumda geçireceğim için çok mutluyum." ifadesine katılımcıların \%63'ü "k1smen kat1lyorum, katıliyorum ya da tamamen katılıyorum" seçeneklerini işaretlemiştir. Bu durum çalışanların çoğunluk itibariyle hiçbir zaman kurumdan ayrılmak istemediğini dolayısıyla bağlılık düzeylerinin yüksek olduğunun kanitıdir.

Dördüncü bağlılık ölçeği "Bu Kurumun sorunlarını gerçekten kendi sorunum olarak görüyorum" ifadesine katılımcıların \%77'si "kısmen katılıyorum, katılıyorum ya da tamamen katılıyorum" seçeneklerini işaretlemiştir. Bu durum çalışanların çoğunluk itibariyle kuruma gönül bağı bulunduğunu göstermesi açısından bağlılık düzeylerinin yüksek olduğunun kanitıdir.

Beşinci bağlılık ölçeği "Bu Kurumda kalmak için bana verilecek tüm görevleri kabul ederim" ifadesine kat1lımcıların \%68'i "kısmen kat1lyorum, kat1lıyorum ya da tamamen katılıyorum" seçeneklerini işaretlemiştir. $\mathrm{Bu}$ durum çalışanların çoğunluk itibariyle çalıştıkları kurumu, mesleki kariyerlerinden bile ayrıcalıklı tutacaklarını göstermesi açısından kuruma olan bağlılık düzeylerinin yüksek olduğunu kanıtıdır.

Sonuç genel olarak değerlendirildiğinde 5 sorudan oluşan örgütsel bağl1lık ölçeği sorularına verilen ifadelerin katılanların \%74'ü tarafindan "kısmen katılıyorum, katıliyorum ya da tamamen katılıyorum" şeklinde işaretlendiği dolayısıyla çalışanların çalıştıkları işletmeye ilişkin bağlılık algılarının yüksek olduğu gözlemlenmiştir.

3.2. İşgörenlere yapılan adalet ölçeği frekans dağılımı sonuçlarına göre aşağıdaki sonuçlara ulaşılmıştır;

Birinci adalet ölçeği "Kurum, çalışanlarının performanslarının karşılığını alması konusunda adaletli davranıyor" ifadesine katılımcıların \%76's1 "kısmen katıllyorum, katılıyorum ya da tamamen katılıyorum" seçeneklerini işaretlemiştir. Bu durum çalışanların ekseriyetle hak ettiği ücreti aldığını ifade ederken, kuruma olan adalet algılarının yüksek olduğunu göstermektedir.

İkinci adalet ölçeği "Kurum, ücretlerin belirlenmesini adaletli biçimde sağlayabiliyor" ifadesine katılımcıların \%70'i "kısmen katılıyorum, katılıyorum ya da tamamen katılıyorum" seçeneklerini işaretlemiştir. $\mathrm{Bu}$ durum kurumun insan kaynakları fonksiyonlarından ücret yönetimi konusunda çok başarılı olduğunu çalışanların çoğunluğu itibariyle bu yönden adalet algı düzeylerinin yüksek olduğunu göstermektedir.

Üçüncü adalet ölçeği "Kurumun performans değerlendirme yöntemlerini adaletli buluyorum" ifadesine katılımcıların \%62'si "k1smen katılıyorum, katılıyorum ya da tamamen katılıyorum" seçeneklerini işaretlemiştir. Bu durum çalışanların bakış açısı ile kurumun, prosedürel adaleti büyük ölçüde sağladığını ispat etmektedir.

Dördüncü adalet ölçeği "Kurum, terfilerin belirlenmesi konusunda adaletli davranıyor" ifadesine katılımc1ların \%89'u "kısmen katıl1yorum, katıl1yorum ya da tamamen 
katılıyorum" seçeneklerini işaretlemiştir. $\mathrm{Bu}$ durum kurumun, çalışanlarının gayretleri karşılığında onlara hak ettikleri kariyer imkânlarının verilebildiğini göstermesi açısından anlamlidir.

Sonuç genel olarak değerlendirildiğinde 4 sorudan oluşan örgütsel adalet ölçeği sorularına verilen ifadelerin katılanların \%74'ü tarafindan 'kısmen katılıyorum, katılıyorum ya da tamamen katılıyorum" şeklinde işaretlendiği dolayısıyla çalışanların çalıştıkları işletmeye ilişkin adalet algılarının yüksek olduğu gözlemlenmiştir.

3.3. İşgörenlere yapılan güven ölçeği sonuçlarına göre aşağıdaki sonuçlara ulaşılmıştır;

Birinci güven ölçeği " $\mathrm{Bu}$ kurumun bana adil davranacağına olan güvenim tamdır" ifadesine katılımcıların \%69'u "k1smen katılıyorum, katılıyorum ya da tamamen katılıyorum" seçeneklerini işaretlemiştir. Bu durum çalışanların çoğunluk itibariyle kurumlarında eşitlik ilkesinden kaynaklı bir güven unsuru olduğunu göstermesi açısından anlamlıdır.

İkinci güven ölçeği " $\mathrm{Bu}$ organizasyonda yöneticiler ve çalışanlar arasındaki güven düzeyi çok yüksektir" ifadesine katılımcıların \%72'si "kısmen katılıyorum, katılıyorum ya da tamamen katılıyorum" seçeneklerini işaretlemiştir. Bu durum çalışanların çoğunluk itibariyle yöneticilerinden memnun olduğunu ve onlarla uyumlu bir çalışma ortamı içersinde birlikte güvenle çalıştıklarını göstermektedir.

Üçüncü güven ölçeği "Birlikte çalıştığım insanlar arasındaki güven düzeyi çok yüksektir" ifadesine katılımcıların \%63'ü "kısmen katılıyorum, katılıyorum ya da tamamen katılıyorum" seçeneklerini işaretlemiştir. Bu durum aynı departman ya da branşta, birlikte benzer işleri yapan çalışanların birbirlerine güvendiklerini böylece de yakalayabilecekleri takım ruhuyla daha verimli çalışabileceklerini göstermesi açısından anlamlıdır.

Dördüncü güven ölçeği "Bu organizasyonda birbirimize güvenme düzeyi çok yüksektir" ifadesine katılımcıların \%68'i "kısmen katılıyorum, katılıyorum ya da tamamen katılıyorum" seçeneklerini işaretlemiştir. Bu durum çalışanların kurumlarında bir güven havası estiğini ve örgüt içi yapının sağlıklı işlediğini göstermesi açısından anlamlıdır.

Sonuç genel olarak değerlendirildiğinde 4 sorudan oluşan örgütsel güven ölçeği sorularına verilen ifadelerin katılanların \%68'i tarafından "kısmen katılıyorum, katılıyorum ya da tamamen katılıyorum” şeklinde işaretlendiği dolayısıyla çalışanların çalıştıkları işletmeye ilişkin güven algılarının yüksek düzeyde olduğu gözlemlenmiştir.

4. Araştırmada örgütsel bağlılık bağımlı değişkeninin, örgütsel güven bağımsız değişkenine hangi oranda bağlı olduğu araştırılmış olup 0,404 düzeyinde bir sonuca ulaşılmıştır.

Yapılan öneriler ise şu şekilde sıralanmıştır:

1. Örgütlerde işgörenlerin gerek gayretlerinin karşılıklarını almalarında gerekse performanslarını arttırabilmelerinde örgüt tarafından sağlanan maddi imkânlar kadar bu imkânların adil bir şekilde uygulanmasının da çalışanlara güven vereceği unutulmamalıdır.

2. İşgörenlerin kararlara katılımı sağlanarak, kendilerine değer verildiği göstermelidir. İşgörenlerden habersiz alınan kararların adaletsizlik oluşturacağı düşünüldüğünde, yöneticiler ve çalışanlar arasında kurulan sağlıklı iletişimlerin güven ortamı oluşturacağı açıktır.

3. Bankacılık sektörü düşünüldüğünde müşterilere daha kaliteli hizmet sunabilmek rekabet şartlarında önemli hale geldiğinden, örgütsel bağlılığın arttırılması ile işgörenler, müşteriler ile daha iyi ilişkiler kurabilecektir. Bu durum ise örgüt çıkarları ile işgören çıkarlarının ortak noktalarda buluşması ile oluşabilecek bir durumdur. Müşterilerden 
(memnuniyet anketleri) alınan geri dönüşümler, işgörenlerin performanslarıyla kıyaslanabileceği gibi işgörenlerin alacakları ödül, prim, ikramiye gibi ücretlerde bu kapsamda örgütsel bağlılığın sağlanması adına değerlendirilebilir.

4. Adaletli bir örgüt havası oluşturmayı başarabilen yöneticiler, bunu uzun vadeli bir politika ve strateji haline getirmelidir. Adalet algısıyla aradığı güven ortamına kavuşan işgörenlerin daha uzun süre örgüt üyeliklerini devam ettirecekleri ve bu üyeliği de gönüllü olarak sürdürecekleri açıktır.Bunun sonucunda da işgören performansındaki artış, örgüt verimliliğine doğrudan yansıyacaktır.

\section{KAYNAKÇA}

Aktuna, M. (2007). İnsan Kaynakları Yönetimi Fonksiyonunun Örgütsel Güvene Etkileri ve Bir Uygulama, Dumlupınar Üniversitesi, Sosyal Bilimler Enstitüsü, Yayımlanmamış Yüksek Lisans Tezi, Kütahya.

Alexander, S. ve Ruderman, M. (1987). The Role of Procedural and Distributive Justice in Organizational Behavior, Social Justice Research, No 1.

Asunakutlu, T. (2001). Klasik ve Neo-Klasik Dönemde Örgütsel Güvenin Karşılaştırılması Üzerine Bir Deneme, Muğla Üniversitesi Sosyal Bilimler Enstitüsü Dergisi, Bahar 2001, Say1 5.

Bakan, İ. (2011). Örgütsel Stratejilerin Temeli Örgütsel Bağl1lık Kavram, Kuram, Sebep ve Sonuçlar, Gazi Kitabevi, Ankara.

Balay, R. (2000). Yönetici ve Öğretmenlerde Örgütsel Bağlılık, Nobel Yayınları, Ankara.

Bansal, H. S., Irving, P. G. ve Taylor, S. F. (2004). A Three Component Model of Customer Commitment to Service Providers, Journal of the Academy of Marketing Science, Volume, 32, No 3.

Becerra, M. ve Gupta, A.K. (2003). Perceived trustworthiness within the organization: The Moderating Impact of Communication Frequency on Trustor and Trustee Effects Organizational Science, Volume 14, No 1.

Benkhoff, B. (1997). Disentangling, Organizational Commitment: The Dangers of the OCQ For Research and Policy, Personel Review, Volume 26, No 1.

Brewer, A. M. (1996). Developing Commitment Between Managers and Employees, Journal of Managerial Psychology, Volume 11, No 4.

Cohen-Charash, Y. ve Spector, P. E. (2001). The Rol of Justice in Organizations: A MetaAnalysis, Organizational Behavior and Human Decision Process, Volume 86, No 2.

Cropanzano, R. ve Folger, R. (1991). Procedural Justice and Worker Motivation, Steers, In R.M., Porter, L.W. (Eds.), Motivation and Work Behavior (131-143) Mcgraw-Hill, New York.

Çakmak K. Ö. (2005). Performans Değerlendirme Sistemlerinde Örgütsel Adalet Algısı ve Bir Örnek Olay Çalışması, İstanbul Üniversitesi, Sosyal Bilimler Enstitüsü, Yüksek Lisans Tezi, İstanbul.

Dailey, R. C. ve Kirk, D. J. (1992).Distributive and Procedurel Justice as Antecedents of Job Dissatisfaction and Intent to Turnover, Human Relations, Volume 45, No 3. 
Demircan, N., Ceylan, A. (2003). Örgütsel Güven Kavramı: Nedenleri ve Sonuçlar, Celal Bayar Üniversitesi, İktisadi ve İdari Bilimler Fakültesi, Yönetim ve Ekonomi Dergisi, Cilt No 10, Sayı 2.

Demirel, Y. (2008). Örgütsel Güvenin Örgütsel Bağlılık Üzerine Etkisi: Tekstil Sektörü Çalışanlarına Yönelik Bir Araştırma, Celal Bayar Üniversitesi, Yönetim ve Ekonomi Dergisi, Cilt No 15, Sayı 2.

Ertürk A. (2008). A Trust-Based Approach To Promote Employees Openness To Organizational Change In Turkey, International Journal of Manpower, Volume 29, Issue 5.

Fields, D. L. (2002). Taking The Measure of The Work, Sage Publication, London.

Folger, R. ve Cropanzono R. (1998). Organizational Justice and Human Resource Management, Sage Publications, London.

Folger, R. ve Konuvsky, M. A. (1989). Effects of Procedural and Distributive Justice On Reavtion To Pay Raise Decisions, Academy of Management Journal, Vol. 32, No 1.

Güçlü, H. (2006). Turizm Sektöründe Durumsal Faktörlerin Örgütsel Bağl1lık Üzerindeki Etkisi, Anadolu Üniversitesi Yayınları, Eskişehir.

Hall, D. T., Schneider, B. ve Nygren, H. T. (1970). Personel Factors in Organizational Identification, Administrative Science Quarterly, No: 15.

Http://www.tbb.org.tr (Erişim tarihi: 05.11.2014).

İnce M. ve Gül H. (2005). Yönetimde Yeni Bir Paradigma: Örgütsel Bağlılık, Çizgi Kitabevi, Konya.

İşbaşı, J. Ö. (2000). Çalışanların Yöneticilerine Duydukları Güvenin ve Örgütsel Adalete İlişkin Algılamalarının Örgütsel Vatandaşlık Davranışın Oluşumundaki Rolü, Akdeniz Üniversitesi, Sosyal Bilimler Enstitüsü, Yüksek Lisans Tezi, Antalya.

Meyer, J. ve Allen, N. (1997). Commitment in the Workplace: Theory, Research and Application, Sage, Tousand Ouks, Ca.

Mishra, J., Morrissey, M.A. (1990). Trust in Employee/Employer Relationships: A Survey of West Michigan Managers, Public Personnel Managment, Volume 19, No 4.

Mowday, R.T., Steers, R. M. ve Porter, L. W. (1979). The Measurement of Organizational Commitment, Journal of Vocational Behavior, No 14.

Nyhan, R. ve Marlowe, H. A. (1997).Development and Psychometric Proparties of the Organizational Trust Inventory, Evaluation Review, Volume 21, No 5.

O'Reilly, C. A. ve Chatman, J. (1986). Organizational Commitment and Psychological Attachment: The Effects of Compliance, Identification and Internalization on Prosocial Behaviour, Journal of Applied Psychology No 71.

Organ, D. W. (1988). A Restatement of the Satisfaction-Performance Hypothesis, Journal of Management, No 14.

Orpen, C. (1994). The effect of organizational commitment on the relationship between procedural and distributive justice, The Journal of Social Psychology, Vol. 134, No 1.

Özler, D. E. (2010).Örgütsel Davranışta Güncel Konular, Ekin Basım Yayın Dağıtım, Bursa. 
Pillai R., Schriesheim, C. B. ve Williams, E. S. (1999). Fairness Perceptions and Trust as Mediators For Transformational and Transactional Leadership, A Two-Sample Study, Journal of Management, No 25.

Polat, S. (2007). Ortaöğretim Öğretmenlerinin Örgütsel Adalet Algıları, Örgütsel Güven Düzeyleri İle Örgütsel Vatandaşlık Davranışları Arasındaki İlişki, Kocaeli Üniversitesi Sosyal Bilimler Enstitüsü, Yayımlanmamış Doktora Tezi, Kocaeli.

Ruyter, K. D. ve Wetzels, M. (1999). Commitment in Auditor-Client Relationships: Antecedents and Consequences, Accounting, Organisations and Society, No 24.

Schminke, M., Ambrose, M. L. ve Cropanzano, R. S. (2000). The Effect of Organizational Structure on Perceptions of Procedural Fairness, Journal of Applied Psychology, Volume 85, No 2.

Straiter, K. L. (2005). The Effects of Supervisors Trust of Subordinates and Their Organization on Job Satisfaction and Organizational Commitment, International Journal of Leadership Studies, Volume 1, No 1.

Sweeney, P. D. ve Mcfarlin, D. B. (1993). Workers Evaluations of the Ends and the Means: An Examination of Four Models Distributive and Procedurel Justice, Organizational Behaviour and Human Decision Processes, Volume 55, No 1.

Şimşek, M. Ş. (2002). Yönetim ve Organizasyon, 6.Bask1, Günay Ofset, Konya.

Tan, H. H. ve Lim, A. (2009), Trust in Coworkers and Trust in Organizations, The Journal of Psychology, Volume 143, No 1.

Taylor, R. G. (1989), The Role of Trust In Labor Management Relations, Organization Development Journal, No 7.

Wahlstrom, K. L. ve Louis, K. S. (2008). How Teachers Experience Principal Leadership: The Roles of Professional Community, Trust, Efficacy and Shared Responsibility, Educational Administration Quarterly, Volume 44, No 4.

Yılmaz, A. ve Atalay, C. G. (2009). A Theoretical Analyze On The Concept of Trust In Organisational Life, European Journal of Social Sciences, Volume 8, No 2.

Yılmaz, K. (2008). The Relationship Between Organizational Trust and Organizational Commitment in Turkish Primary Schools, Journal of Applied Sciences, Vol. 8, No 12.

Zaheer, A., McEviley B. ve Perrone V. (1998). Does Trust Matter? Exploring The Effects Interorganizational and Interpersonel Trust, On Performance Organization Science, No 9. 